\title{
The siliciclastics/carbonates shift in the Jurassic of the Western Caucasus (central northern Neo-Tethys): reconsidering research over the last 50 years
}

\author{
Dmitry A. Ruban ${ }^{1,2,3}$ \\ ${ }^{1}$ K.G. Razumovsky Moscow State University of Technologies and Management (the First Cossack University), \\ Zemlyanoy val 73, Moscow, 109004 Russia \\ ${ }^{2}$ Cherepovets State University, Sovetskiy Avenue 10, Cherepovets, Vologda Region, 162600 Russia \\ ${ }^{3}$ P.O. Box 7333, Rostov-na-Donu, 344056 Russia \\ e-mail: ruban-d@mail.ru
}

\begin{abstract}
A chain of carbonate platforms evolved in the northern Neo-Tethys during the Late Jurassic, but current knowledge remains incomplete as long as data from several larger regions, such as the Western Caucasus, are not included. In order to fill this gap, it is here suggested to reconsider the information accumulated chiefly during Soviet times. Although these data are too general, they still matter with regard to some regional characteristics and tentative interpretations. Available data on the spatio-temporal distribution of Bajocian-Callovian sedimentary rocks are summarised in a novel way which permits documentation of depositional trends at six representative localities in the Western Caucasus. The extent of the carbonate platform increased at two localities since the Late Callovian and at a third since the Middle Oxfordian. Three additional sites were characterised either by non-deposition or deep-marine sedimentation. The onset of carbonate platform development marked a remarkable shift from chiefly siliciclastic to carbonate deposition, although this event was not sudden everywhere. The Bathonian pulse of tectonic activity, coupled with the eustatic sea level rise, allowed shelves to expand during the Callovian-Oxfordian, with a reduction in siliciclastic input from islands and seawater that became well oxygenated and warmer. These conditions were conducive to biogenic carbonate production, allowing the carbonate platform to expand subsequently.
\end{abstract}

Key words: carbonate platform, geoscience tradition, Mountainous Adygeya, Middle Jurassic, regional stratigraphy

\section{Introduction}

Periods of carbonate platform development were significant and occasionally long-term episodes in the geological history of numerous sedimentary basins, continental margins and large segments of oceans, as illustrated in 'classic' papers by Read (1982, 1985), Pomar (2001), Bosence (2005) and Williams et al. (2011). More recently, significant contributions have been in particular by Lüdmann et al. (2013), Betzler et al. (2014), Pomar \& Haq (2014),
Fralick \& Riding (2015), Brandano et al. (2017), Morsilli et al. (2017) and Tendil et al. (2018). Although carbonate platforms rank amongst the most intensively studied geological phenomena, our knowledge of them remains incomplete to a certain degree, which is connected to the general tendency of modern geologists to focus on some, well-known carbonate platforms only. Thus, to gather additional data on other, lesser-known carbonate platforms and interpret these in a modern conceptual frame, is an important task. 
During the Late Jurassic, a huge carbonate platform evolved in the Caucasian domain of the Neo-Tethys Ocean (Fig. 1). This has been characterised in papers by Boiko et al. (1977), Kuznetsov (1993), Ruban (2006a, 2008a) and Guo et al. (2011). However, descriptions and interpretations of those authors are of a general nature and hint at significant uncertainties, gaps and inconsistencies in currently available data. For instance, one enigma of the Late Jurassic carbonate platform is its apparently sudden onset near the end of the Callovian Stage. During one million year, or less, carbonate deposition became a characteristic feature of the region, although carbonate strata are nearly completely absent in the underlying Early-Middle Jurassic levels. More generally speaking, a better view of the siliciclastics/carbonates shift in the Western Caucasus may contribute substantially to our understanding of the onset of carbonate platform development in the entire northern Neo-Tethys. Although this region has not been in the focus of international stratigraphical and sedimentological research to date (and, most probably, will not be in the near future), data acquired earlier during Soviet times may help to fill the 'Caucasian gap' in our picture of carbonate evolution in the northern Neo-Tethys during the Late Jurassic. In any case, this information

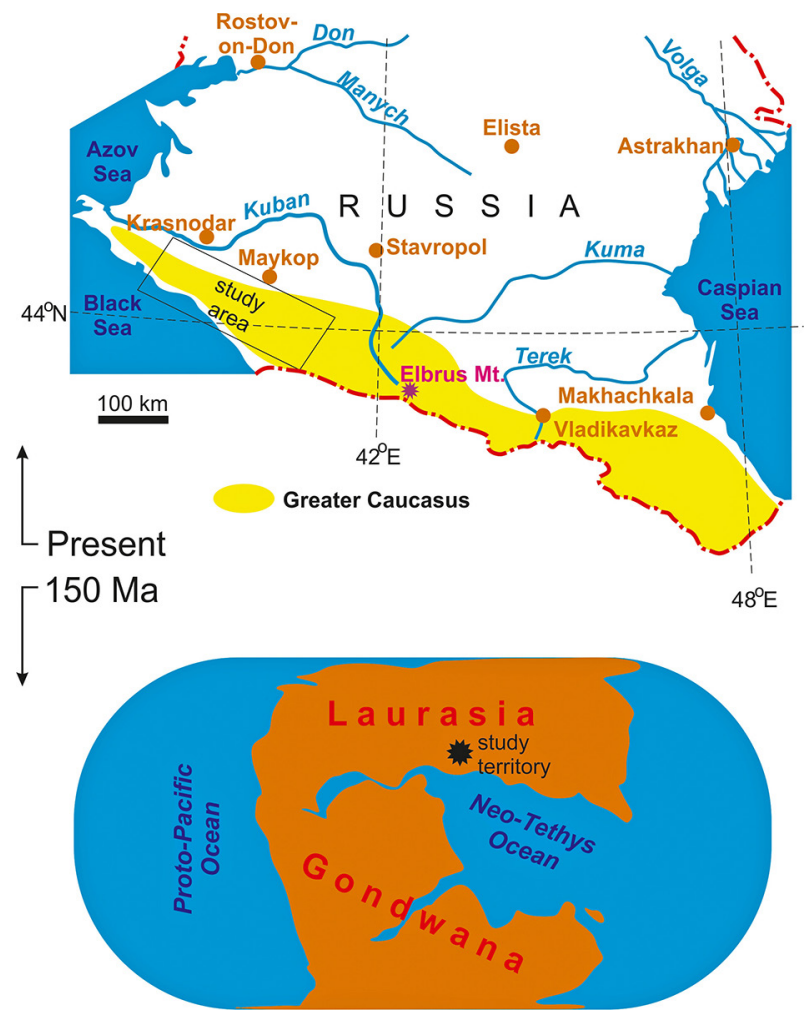

Fig. 1. Geographical and palaeogeographical location of the study area. The palaeogeographical base map for $150 \mathrm{Ma}$ is simplified from Matthews et al. (2016) may help introduce Jurassic geology of the Western Caucasus to the international research community and formulate agendas for further research.

The main objective of the present paper is to provide an update of available data on the spatio-temporal distribution of carbonates across the Middle/ Late Jurassic transition in the Western Caucasus. Personal observations made during two decades of field work have facilitated such an update. Additionally, some novel interpretations of this updated information are undertaken in order to demonstrate the importance of the Western Caucasus for our understanding of changes in sedimentation along the northern periphery of the Neo-Tethys during the Middle and Late Jurassic.

\section{Geological setting}

The Greater Caucasus is a large, elongated, mountainous and tectonically active domain that stretches from the Black Sea in the west to the Caspian Sea in the east (Fig. 1A). Its western part, referred to as the Western Caucasus, is situated in the very southwestern part of Russia. It is drained by north-flowing tributaries of the River Kuban and also extends along the Black Sea coast. The Western Caucasus, and the region of Mountainous Adygeya in particular, hosts several national/international tourist destinations, the increased popularity of which has led to better accessibility of many geological features during the past twenty years.

Geologically, the Greater Caucasus is an orogen of Late Cenozoic age (Rolland, 2017) that has a typical fold-and-thrust tectonic architecture. However, the majority of sedimentary complexes that crop out within this domain are of Mesozoic age; during that time back-arc basins and island arcs evolved (Saintot et al., 2006; Ruban, 2006b, 2008a; McCann et al., 2010; Adamia et al., 2011). This region was part of the northern periphery of the Neo-Tethys Ocean during the Jurassic (Golonka, 2004; Matthews et al., 2016), being situated in the central part of this periphery (Fig. 1B). Jurassic deposits are distributed widely in the Western Caucasus (Rostovtsev et al., 1992; Ruban, 2008b) and include thick (up to $10 \mathrm{~km}$ ) siliciclastic packages of Early-Middle Jurassic age and less thick, albeit representative, carbonate and evaporitic levels of Late Jurassic age. The former are more strongly folded, whereas the latter are less intensively dislocated and form a kind of monocline. The existence of a large carbonate platform in the Western Caucasus was discussed by Kuznetsov (1993) and Guo et al. (2011), and some general features of relevant deposits were described by Boiko et al. (1977) and Ruban 
(2006a, 2008a). The carbonate platform deposits crop out at many places in the Western Caucasus and, particularly, in the vicinity of the Lagonaki Highland (Fig. 2). Although detailed facies analysis, with recognition of microfacies types and standard facies associations, still needs to be carried out, it is possible to distinguish terrestrial (alluvial sandstones), shallow-marine (nearshore siliciclastics and inner ramp/shelf carbonates) and deep-marine (siliciclastic turbidites) depositional environments across the Middle/Late Jurassic transition.

Jurassic deposits accumulated in elongated, semi-enclosed basins that experienced significant tectonic activity during the Early and Middle Jurassic and subsidence during the Late Jurassic (Saintot et al., 2006; Ruban, 2008a, 2010a; McCann et al., 2010; Adamia et al., 2011). Palaeogeographically, this territory was embraced by the Caucasian Sea, a marginal sea of the Neo-Tethys Ocean (Ruban, 2006b). In addition to the territory of the present-day Greater Caucasus, this sea also occupied some areas to the north (i.e., the present Ciscaucasus) and reached the southern edge of the Russian Platform. However, the main domain of marine sedimentation and the deepest parts of the sea stretched across the study area. The Caucasian Sea occupied the Greater Caucasus basin, which was essentially a back-arc basin located between an island arc in the south (with the deepest, axial part of the basin situated closely to this arc) and an extensive, slightly inclined shelf of the Russian Platform in the north.

\section{Methodology}

\subsection{The Soviet research legacy and its utility for modern studies}

The Jurassic sedimentary rocks of the Greater Caucasus have been studied for over a century, but the most important advances were made in the second half of the twentieth century. Extensive regional studies were initiated in the later 1940s and culminated at the beginning of the 1990s. The main outcome of this research is the monograph by Rostovtsev et al. (1992) which supplies a modern view of the Jurassic stratigraphy in the region. In order to understand how to assess the utility of research over the last 50 years, it is necessary to characterise the specific features ('traditions') of Soviet geoscience research, in part carried into modern times.

Soviet geoscience research was focused on large territories, general geological descriptions and conceptual (theoretical) developments. The main advantages of this research were the following:

- generalisation, systematisation and conceptualisation of geological information;

- creation of multiple classifications of geological phenomena;

- development of advanced terminology.

Such 'traditions' would be very useful in current international geosciences so as to avoid methodological replications, a too narrow focus and production of fragmented knowledge without a well-de-

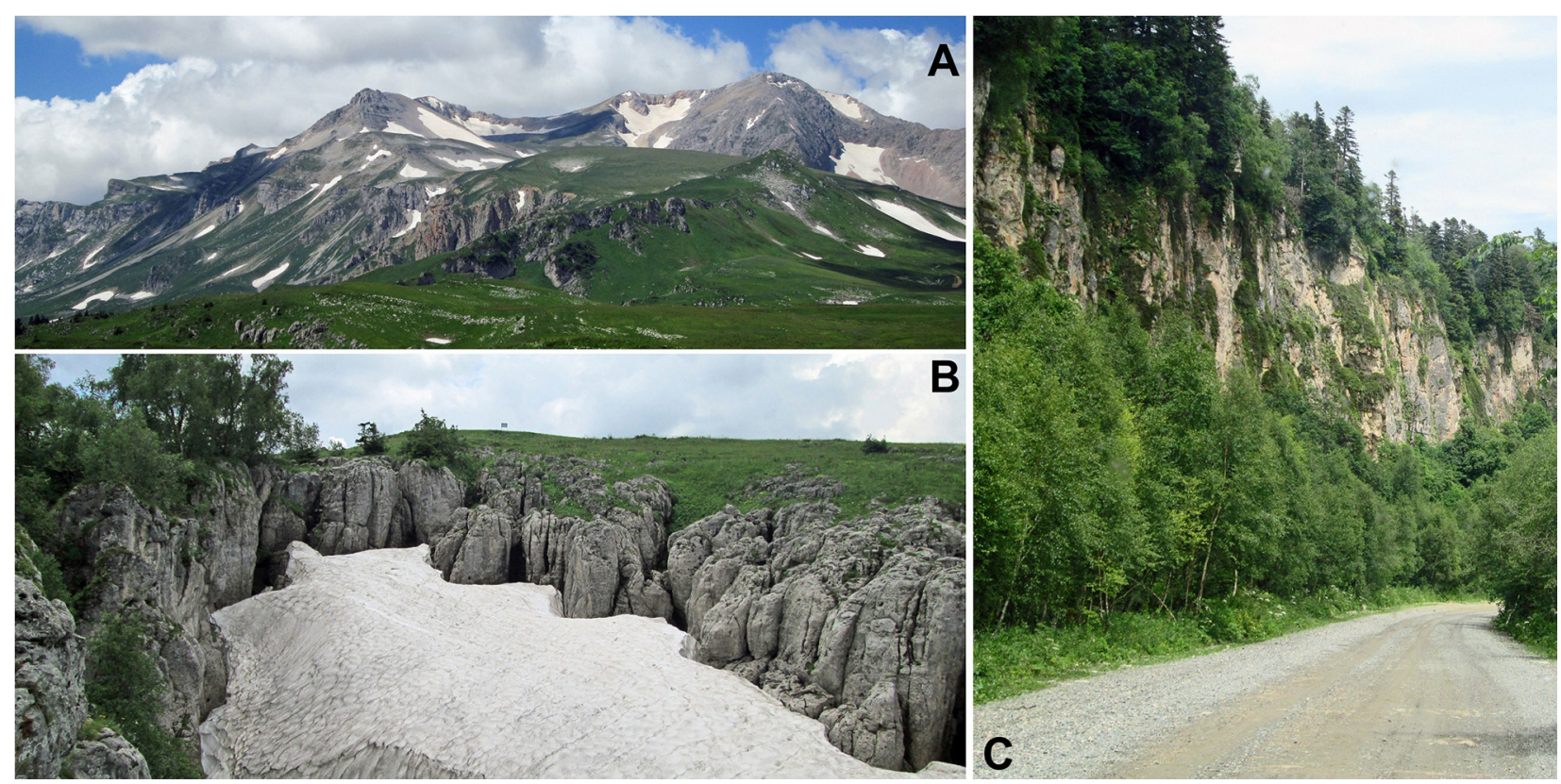

Fig. 2. Late Jurassic carbonate outcrops in the Western Caucasus (all representing locality $a$ discussed later, see Fig. 3): A - Reefal carbonates of the Oshten Mountain; B - Karstified limestones of the Stonesea Range; C - Massive carbonates of the Flatiron Plateau 
veloped theoretical foundation. However, there were also disadvantages, as follows:

- loss of many details;

- poor attention to auxiliary information about less common phenomena;

- less attention to representative sections than to composite, regional-scale sections (however, this bias allowed more balanced information to be obtained when data from multiple small outcrops were taken into account);

- little research attachment to sedimentary basins;

- avoiding competing research (topics, objects and age preferred by one researcher or research group were often specifically avoided by other specialists).

The legacy of such research differs significantly, and often essentially, from geological data generated by European or American colleagues.

As a consequence of such 'traditions', our knowledge of Jurassic sedimentary packages of the Western Caucasus is as follows: well-justified, albeit too general, descriptions of formations are available (Rostovtsev et al., 1992), as based on data from more or less laterally extensive sections and numerous small outcrops. However, these sections and outcrops themselves were not described with due attention and even their exact location often remains unknown. In other words, descriptions are based mainly on composite sections that represent large areas, and these differ essentially from data available on European carbonate platforms (e.g., Tendil et al., 2018). Facies interpretations are also available (Ruban, 2008b), but these are of a general character, because microfacies types, facies associations and other features were examined too generally or not examined at all. In any case, such interpretations can be justified only when the above-mentioned composite sections are considered; thus, by definition, they lack details.

The Soviet stratigraphical and sedimentological research legacy poses a dilemma: should the Jurassic sedimentary packages of the Western Caucasus be restudied in detail using modern geoscientific approaches and replace the Soviet legacy, or can the latter be employed anyhow? In this respect, three matters are here considered. Firstly, the Western Caucasus is a very large (up to 30,000 square kilometres) and geologically complex territory; to study it in detail would take decades of research by dozens of specialists. Not a single research project can complete such an ambitious task. However, data on this region (e.g., on Late Jurassic carbonate platforms) are called for right now. In addition, geological research activity in this region is close to zero for many topics; in other words, modern stratigraphi- cal and sedimentological investigations have been very rare for the past 25 years. Secondly, a specific feature of the Western Caucasus is the presence of numerous small Jurassic outcrops 'dispersed' over a large territory. In such cases, composite sections that represent large areas, even if described too generally, may provide valuable data on regional interpretations than may single sections studied in detail. Thirdly, the Soviet legacy is suitable for consideration as tentative, yet meaningful, evidence from this important region that allows some interesting, albeit general, interpretations for the entire Western Caucasus to be made. Such are sufficient to fill the gap in our knowledge of Mesozoic carbonate platforms on a Tethyan scale.

With regard to reasons specified above, it is here suggested that the available data from Soviet research efforts should be reconsidered wherever necessary and possible. In this updated form, it can then be made available to the international research community. In addition to filling evident gaps in our knowledge, these data can be used to forward some hypotheses and to formulate agendas for further research. Undoubtedly, the latter should be based on modern stratigraphical and sedimentological approaches, with the focus on representative sections, detailed facies analysis, sequence-stratigraphical interpretations and more.

\subsection{Resolving stratigraphical uncertainty}

The present study focuses on spatio-temporal relationships of Middle and Late Jurassic sedimentary packages. The work by Rostovtsev et al. (1992) contains descriptions of all Jurassic formations in numerous areas (zones) of the Greater Caucasus and is a good example of the above-mentioned Soviet legacy. The use of individual representative sections of Jurassic strata is impossible, because such sections are almost absent. More precisely, each area represents a single fragmented section that consists of numerous small outcrops (for an update, see Ruban, 2008b). These areas are distinguished on the basis of lithological dissimilarities and relationships with tectonic elements. However, their nomenclature differs substantially for the Hettangian-Bathonian and Callovian-Tithonian intervals. On the one hand, such a difference is inevitable in view of marked changes in the character of sedimentation and significant tectonic reorganisation across the Bathonian/Callovian transition. On the other hand, this difference does not permit the establishment of spatio-temporal relationships between the sedimentation in the western part of the 
Greater Caucasus basin during the Early/Middle and Late Jurassic.

In the present paper, I try to normalise the typology of sedimentary successions, and my analysis is restricted to:

- the Bajocian-Oxfordian interval, representing the siliciclastics/carbonates shift;

- the Western Caucasus where this platform has been studied best.

Spatial correspondence of the areas distinguished by Rostovtsev et al. (1992) and Ruban (2008b) is also established so as to outline several larger areas that reflect the entire Jurassic sedimentary succession. Some field observations made by myself have facilitated identification of links between pre-Callovian and post-Bathonian packages. In order to avoid terminological confusion, these areas are here referred to as 'localities'. A total of six localities $(a-f)$ are established for the Western Caucasus (Fig. 3). For each of these, data on sedimentary packages are generalised in order to outline composite sections. This is a very novel vision that permits to trace the onset of carbonate platform development. In other words, this analysis is based on the Soviet research legacy, but its outcome (i.e., a scheme that depicts the regional distribution of sedimentary rocks across the Middle/Late Jurassic transition) is new.

In the present paper, the standard regional ammonite biozonation (Rostovtsev et al., 1992) is employed, as is the current version of the geological time scale approved by the International Commission on Stratigraphy (Ogg et al., 2016; see updates at www.stratigraphy.org). Depositional environments are interpreted for all sedimentary packages, following the same principles as in Ruban (2008b).

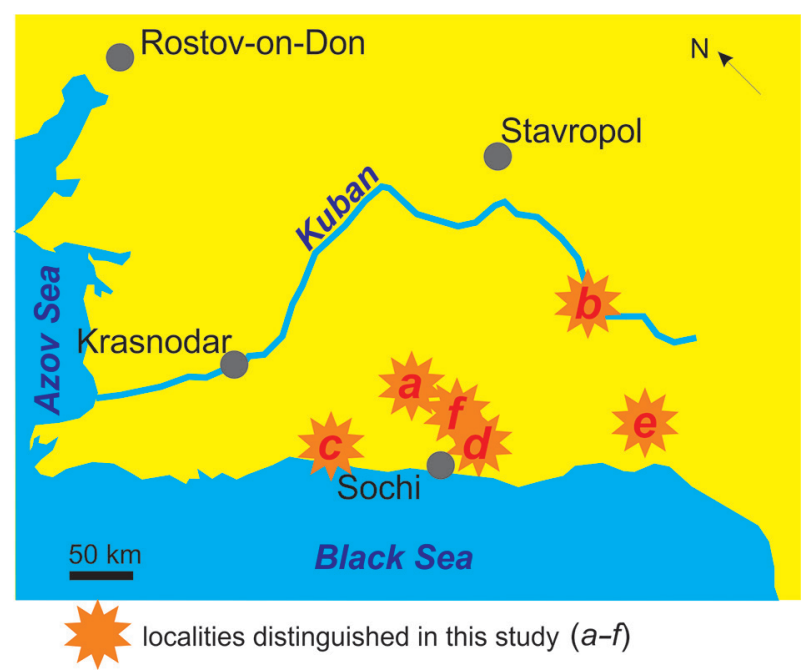

Fig. 3. Locations of areas considered in the present study

\section{Results}

The six localities $(a-f)$ established differ in the composition and thickness of the Bajocian-Oxfordian sedimentary successions (Fig. 4). These are characterised briefly below:

1. Locality a (Lagonaki Highland and vicinity) thick Bajocian-Bathonian shales and sandstones, overlain unconformably by thin Callovian siliciclastics and moderately thick reefal Oxfordian carbonates;

2. Locality $b$ (basins of the rivers Belaja and Laba) thick Bajocian-Bathonian shales, terrestrial late Bathonian sandstones, moderately thick Callovian siliciclastics and Oxfordian carbonates;

3. Locality $c$ (western edge of Greater Caucasus) thick Bajocian shales and extended post-Bajocian hiatus;

4. Locality $d$ (southern slopes of Greater Caucasus along the Black Sea coast) - moderately thick Bajocian shales and volcanics overlain unconformably by Callovian-Oxfordian siliciclastics with some carbonate layers;

5. Locality $e$ (vicinity of the city of Sochi and northern Abkhazia) - very thick Bajocian shales and volcanics, thin Bathonian siliciclastics overlain by mixed siliciclastic-carbonate Callovian-Oxfordian package that becomes carbonate-dominated in its upper part;

6. Locality $f$ (axial part of Greater Caucasus in study area) - hiatus.

The reconstructed spatio-temporal distribution of Bajocian-Oxfordian sedimentary packages implies a heterogeneity of depositional processes in the Western Caucasus (Fig. 4A, B). At localities $a$ and $b$, the Bajocian-Bathonian interval is dominated by deep-marine siliciclastics without carbonate layers. After a short time span of non-deposition, a thin siliciclastic package accumulated during the Callovian, to be followed by the start of massive carbonate accumulation already before the end of this stage. At locality $e$, the tendency was similar, although episodic carbonate accumulation started earlier and this accumulation became massive only during the middle Oxfordian. At localities $c$ and $f$, non-deposition prevailed within the time interval analysed. Most distinct is locality $d$ where deep-marine siliciclastic deposition (with rare episodes of slope-carbonate accumulation) was restored after the Bathonian hiatus.

Generally speaking, it is possible to conclude that there was a marked change in the character of regional sedimentation, i.e., the shift from siliciclastics to carbonates. However, the onset of carbonate platform development during the Callovian-Oxfor- 
dian was not as sudden, nor as spatially extensive, as usually assumed. The appearance of carbonate layers was gradual at at least one locality $(e)$ and there was no carbonate platform at all over half of the study area (i.e., localities $c, d$, and $f$ ) (Fig. 4A). The timing of carbonate platform development at localities $a$ and $b$ corresponds to the boundary between the middle and late Callovian substages (i.e., base of Peltoceras athleta ammonite Zone) (Rostovtsev et al., 1992). At locality $e$, this started much later, i.e., when massive carbonate deposition with coral reefs began during the middle Oxfordian (base of Gregoryceras transversarium ammonite Zone) (Rostovtsev et al., 1992). With regard to the geological time scale (Ogg et al., 2016; see updates at www. stratigraphy.org), this delay in carbonate platform development equates to 3 myr.

\section{Discussion}

\subsection{Palaeogeographical interpretation}

The relative spatial position of the localities established (Fig. 3) and knowledge of the geometry of the Caucasian basins during the Jurassic (Ruban, 2006b, 2010a; Saintot et al., 2006; McCann et al., 2010) permits to outline palaeogeographical changes in the Western Caucasus across the Middle/Late Jurassic transition. Localities $a, b$, and $e$ represent marginal parts of the sedimentary basin that was embraced by the Caucasian Sea. Locality $d$ illustrates the deepest axial part of this basin, or depocentre. Localities $c$ and $f$ refer to the small island-arc land mass; however, the deep-marine part of the basin embraced locality $c$ during the Middle Jurassic.

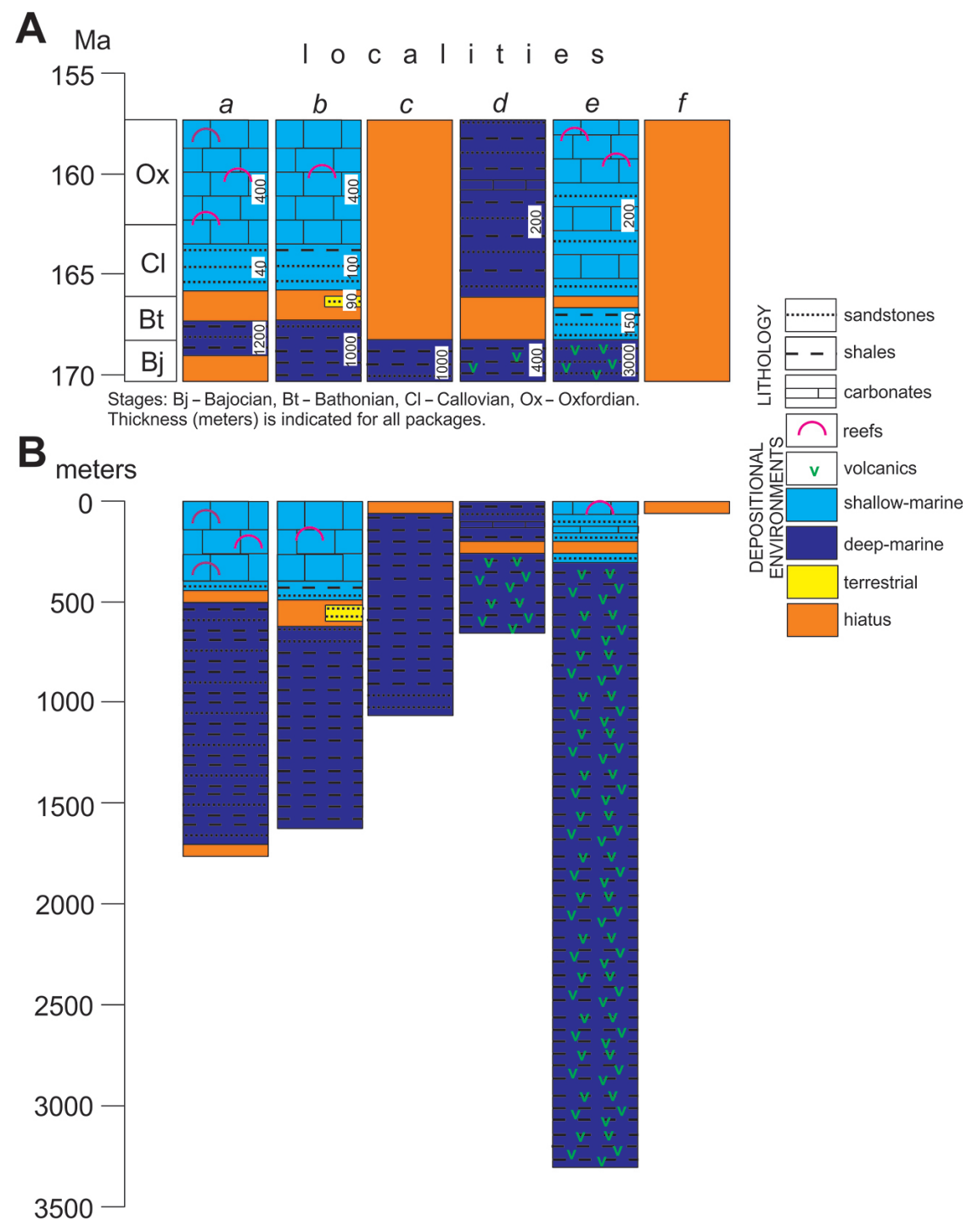

Fig. 4. Spatio-temporal relationships of sedimentary packages across the Middle/Late Jurassic transition in the Western Caucasus: A - Justified to the numerical time scale; $\mathbf{B}$ - Justified to the thickness of sedimentary packages 
During the Bajocian, the study area corresponded to a deep-marine basin with narrow shelves around the islands. The Bathonian pulse of tectonic activity and relevant structural reorganisation (Ruban, 2010a) led to a partial closure of the backarc basins and extension of shelfal environments during the Callovian-Oxfordian. The latter stage hosted the carbonate platform (Fig. 4A). Importantly, shelves developed along the northern margin of the Caucasian Sea and around the islands in its central part. Therefore, the spatial configuration of the carbonate platform appears to be highly complex, and determination of its type (Kuznetsov, 1993; Ruban, 2006a; Guo et al., 2011) remains a challenge. The presence of significant carbonate buildups along the edge of this platform (Boiko et al., 1977; Rostovtsev et al., 1992; Ruban, 2006b) would suggest a rimmed shelf type to be the most plausible.

\subsection{Mechanism of the onset of carbonate platform development}

It appears to be very important to add novel data on possible regional and global controls on Jurassic sedimentation in the Western Caucasus. In particular, new eustatic developments by Haq (2018) need to be considered, as well as our novel understanding of palaeogeographical changes in the Western Caucasus across the Middle/Late Jurassic transition (see above). The mechanism of the onset of carbonate platform development can be reconstructed through qualitative evaluation of the temporal correspondence of principal factors that influenced the depositional system of the Western Caucasus during the time slice analysed. With regard to the shift from siliciclastics to carbonates in the Western Caucasus, three questions have to be answered:

- why did the carbonate platform appear only in the late Callovian-Oxfordian and why were carbonates almost totally absent earlier?

- why did carbonate sedimentation start first at locality $e$ and only later at localities $a$ and $b$ ?

- why was the onset of carbonate platform development sudden at localities $a$ and $b$, unlike locality $e$ ?

During the Bajocian-Bathonian, the study area was characterised by the presence of semi-enclosed, deep-marine basins which were the result of the tectonic framework of the area (Ruban, 2006b, 2010a), as well as the relatively low global sea level (Haq, 2018). Oxygen-depleted conditions were very typical of these basins; the Bajocian-Bathonian shales are often dark coloured on account of organic matter (Rostovtsev et al., 1992; Ruban, 2010b). Active development of island arcs led to denudation of relevant land masses, as a result of which there were voluminous fluxes of siliciclastic matter to the basins. Very thick packages of shales formed within a very short time (Fig. 4B). Moreover, the Caucasian Sea was fairly warm prior to the Callovian, but not as warm as during the Late Jurassic (Jasamanov, 1978; Ruban, 2006a). The conditions described restricted the growth of benthic communities and, thus, these conditions appear to have been unfavourable for carbonate sedimentation.

The Bathonian pulse in regional tectonic activity brought a marked change (Ruban, 2010a). Initially, it led to significant uplift of the study area with non-deposition almost everywhere (Fig. 4A), despite a global eustatic rise (Haq, 2018). However, the territory later subsided (Saintot et al., 2006), and the ongoing eustatic rise led to rapid transgression over the domain that experience uplift previously. As a result, the Caucasian Sea became shallow-marine, with the only limited areas of deep-marine sedimentation, as 'remnants' of the Middle Jurassic basins. The initiation of a shallow sea and its external opening (as a result of regional subsidence and global sea level rise; see Haq, 2018) led to oxygenation of the seawater. At the same time, a kind of 'stabilization' of island arcs and drowning of parts of these reduced their denudation with a subsequent decrease in fluxes of siciliclastic material. Finally, seawater temperature became high (Jasamanov, 1978; Ruban, 2006a). The changes described above led to the appearance of conditions that were conducive to blooms of benthic communities, which in turn led to massive carbonate production and deposition. This complex mechanism, involving regional tectonic, global eustatic and palaeoclimatic controls (Fig. 5), explains the onset of carbonate platform development in the Western Caucasus during the Callovian-Oxfordian.

The earlier start of carbonate sedimentation at locality e can be explained by the fact that the Bathonian tectonic pulse did not result in any significant uplift. This is well reflected by the short duration of the hiatus that preceded the episode of shallow-marine sedimentation (Fig. 4A). As a result, the Callovian transgression led to a rapid exposure of niches for carbonate-producing marine biota. At localities $a$ and $b$, the environments 'stabilized' slightly, during the late Callovian. These localities occupied positions on the periphery of the former deep-marine basin that disappeared together with the Bathonian tectonic reorganisation of the territory. The relevant areas were inundated during the Early Callovian with siliciclastic sedimentation resulting from the denudation of the Bathonian island-arc land mass- 


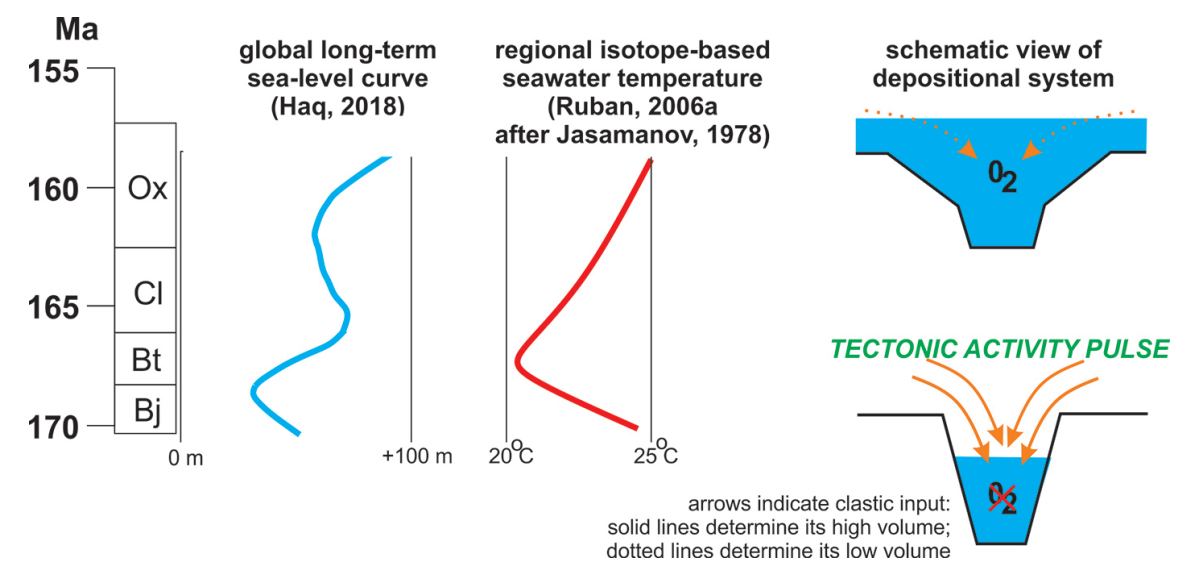

Fig. 5. Schematic representation of conditions explaining the onset of Late Jurassic carbonate platform development in the Western Caucasus

es. The coupled effect of further subsidence (Saintot et al., 2006) and eustatic rise (Haq, 2018) produced a rapid rise of shelfal environments and opened space for carbonate production. Generally, the second and third questions should be answered with regard to the position of the localities relative to the geometry of the pre-existing deep-marine basin and island arc.

\subsection{Comparison to other carbonate platforms}

My interpretations for the onset of Late Jurassic carbonate platform development in the Western Caucasus are worthy of comparison with available data on some other Tethyan carbonate platforms. Two representative examples are the Early Cretaceous Urgonian carbonate platform in southeastern France and northwestern Switzerland and the Middle/Late Jurassic Gissar carbonate platform of Uzbekistan. In spite of differences in geometry, palaeogeographical setting and carbonate factories, some general comparisons to these carbonate platforms appear feasible.

The start of Urgonian carbonate platform development was asynchronous, but rather sudden; however, carbonate deposition also occurred prior to its onset (Clavel et al., 2013, 2014; Frau et al., 2018; Tendil et al., 2018). Regional tectonic activity, eustatic fluctuations, palaeoclimate and oxygen depletion episodes were important controls on platform evolution (Tendil et al., 2018). Importantly, the latter was linked strongly to the development of the deep Vocontian Basin. The onset of Gissar carbonate platform development, which resembled the Late Jurassic platform of the Western Caucasus, was also sudden, although carbonate layers had formed from time to time in the Middle Jurassic deep-marine environments (Carmeille et al., 2018). An important control of platform evolution was the tectonic inheritance, i.e., its links to the tectonic structures and reorganisations that occurred prior to the beginning of platform development (Carmeille et al., 2018).

Two general inferences are possible:

- the onset of carbonate platform development was more or less sudden in several cases, although the striking changes in sedimentation character that have been registered in the Western Caucasus appear to be exceptional;

- the mechanisms facilitating the appearance of carbonate platforms were always complex, but these were often linked to regional tectonic activity and certain structural reorganisations of the territories.

Indeed, further comparisons are called for in order to understand how typical and how exceptional was the shift from siliciclastics to carbonates in the Western Caucasus. When comparing the Western Caucasus to other platforms, it is important to point out that, unlike land-attached ramps and carbonate shelves, the flat-lying isolated (intraoceanic) Tethyan platforms were characterised by a predominantly synchronous and rapid onset of carbonate sedimentation. Such was the case in the Apulia (Morsilli et al., 2017), the Apenninic (Mostardini \& Merlini, 1986) and the Adriatic carbonate platforms (Husinec and Jelaska, 2006). Similarly important would be a comparison with nearby Late Jurassic carbonate platforms, e.g., those of the Crimean Peninsula. However, our knowledge of these also calls for additional, and improved, details.

\section{Conclusions}

Two principal outcomes of the present study, which reconsiders the legacy of previous research, are as follows: 
- the onset of Late Jurassic carbonate platform development in the Western Caucasus marked a major shift from siliciclastics to carbonates, but it was not too sudden;

- the mechanism that explains the onset of carbonate platform development during the Callovian-Oxfordian was highly complex, and it included both basin-scale (tectonic activity, oxygen depletion and seawater temperature) and global (eustasy) factors.

Undoubtedly, the evolution of the Caucasian carbonate platform deserves closer attention on the part of the international research community. On the one hand, its consideration facilitates judgments of general regularities in carbonate platform growth. On the other hand, the study of this platform permits to fill a significant gap in our understanding of Mesozoic sedimentation in the central northern Neo-Tethys. This means that modern stratigraphical and sedimentological investigations of the Middle-Late sedimentary packages of the Western Caucasus should be put on the research agenda. The three most important tasks for future studies are:

- to find representative sections and document these in detail;

- description of microfacies types and facies associations;

- accurate 3D reconstructions of the sequence-stratigraphical architecture.

Achieving these goals would appear to be impossible without extensive field work and application of modern descriptive techniques.

\section{Acknowledgements}

I am grateful to the journal editor and both anonymous reviewers for providing important suggestions, to N.V. Ruban (Russia) for accompanying me in the field, and to colleagues from the Southern Federal University (Russia) for assistance in various ways.

\section{References}

Adamia, S., Alania, V., Chabukiani, A., Kutelia, Z. \& Sadradze, N., 2011. Great Caucasus (Cavcasioni): A Longlived North-Tethyan Back-Arc Basin. Turkish Journal of Earth Sciences 20, 611-628.

Betzler, C., Lindhorst, S., Eberli, G.P., Lüdmann, T., Möbius, J., Ludwig, J., Schutter, I., Wunsch, M., Reijmer, J.J.G. \& Hübscher, C., 2014. Periplatform drift: The combined result of contour current and off-bank transport along carbonate platforms. Geology 42, 871874.

Boiko, N.I., Sedletskij, V.I. \& Shvedov, V.N., 1977. Litologo-fatsial'nye osobennosti i uslovija obrazovanija karbonatnykh otlozhenij oksforda v Zapadnom Predkavkaz'e. Litologija i poleznye iskopaemye 1, 137-144 (in Russian).

Bosence, D., 2005. A genetic classification of carbonate platforms based on their basinal and tectonic settings in the Cenozoic. Sedimentary Geology 175, 49-72.

Brandano, M., Cornacchia, I. \& Tomassetti, L., 2017. Global versus regional influence on the carbonate factories of Oligo-Miocene carbonate platforms in the Mediterranean area. Marine and Petroleum Geology 87, 188-202.

Carmeille, M., Bourillot, R., Brunet, M.-F., Pellenard, P., Fürsich, F.T., Schnyder, J., Barrier, E., Blanpied, C. \& Sidorova, I., 2018. Architecture and sedimentary evolution of the southwestern Gissar carbonate platform (Uzbekistan) during the Middle-Late Jurassic. Marine and Petroleum Geology 97, 437-465.

Clavel, B., Charollais, J., Busnardo, R., Granier, B., Conrad, M., Desjacques, P. \& Metzger, J., 2014. La plateforme carbonatée urgonienne (Hauterivien supérieur - Aptien inférieur) dans le Sud-Est de la France et en Suisse: synthèse. Archives des Sciences 67, 1-100.

Clavel, B., Conrad, M.A., Busnardo, R., Charollais, J. \& Granier, B., 2013. Mapping the rise and demise of Urgonian platforms (Late Hauterivian - Early Aptian) in southeastern France and the Swiss Jura. Cretaceous Research 39, 29-46.

Fralick, P. \& Riding, R., 2015. Steep Rock Lake: Sedimentology and geochemistry of an Archean carbonate platform. Earth-Science Reviews 151, 132-175.

Frau, C., Tendil, A.J.-B., Lanteaume, C., Masse, J.-P., Pictet, A., Bulot, L.G., Luber, T.L., Redfern, J., Borgomano, J.R., Léonide, Ph., Fournier, F. \& Massonnat, G., 2018. Late Barremian-early Aptian ammonite bioevents from the Urgonian-type series of Provence, southeast France: Regional stratigraphic correlations and implications for dating the peri-Vocontian carbonate platforms. Cretaceous Research 90, 222-253.

Golonka, J., 2004. Plate tectonic evolution of the southern margin of Eurasia in the Mesozoic and Cenozoic. Tectonophysics 381, 235-273.

Guo, L., Vincent, S.J. \& Lavrishchev, V., 2011. Upper Jurassic Reefs from the Russian Western Caucasus: Implications for the Eastern Black Sea. Turkish Journal of Earth Sciences 20, 629-653.

Haq, B.U., 2018. Jurassic Sea-Level Variations: A Reappraisal. GSA Today 28, 4-10.

Husinec, A. \& Jelaska, V., 2006. Relative sea-level changes recorded on an isolated carbonate platform: Tithonian to Cenomanian succession, southern Croatia. Journal of Sedimentary Research 76, 1120-1136.

Jasamanov, N.A., 1978. Landshaftno-klimatitchieskije uslovija jury, mela i paleogena Juga SSSR [Landscape-climatic conditions of the Jurassic, the Creaceous, and the Paleogene in the South of the USSR]. Moskva (Nedra), 224 pp. (in Russian).

Kuznetsov, V.G., 1993. Late Jurassic - Early Cretaceous carbonate platform in the northern Caucasus and Pre- 
caucasus. American Association of Petroleum Geology, Memoirs 56, 455-463.

Lüdmann, T., Kalvelage, C., Betzler, C., Fürstenau, J. \& Hübscher, C., 2013. The Maldives, a giant isolated carbonate platform dominated by bottom currents. Marine and Petroleum Geology 43, 326-340.

Matthews, K.J., Maloney, K.T., Zahirovic, S., Williams, S.E., Seton, M. \& Müller, R.D., 2016. Global plate boundary evolution and kinematics since the late Paleozoic. Global and Planetary Change 146, 226-250.

McCann, T., Chalot-Prat, F. \& Saintot, A., 2010. The Early Mesozoic evolution of the Western Greater Caucasus (Russia): Triassic-Jurassic sedimentary and magmatic history. Geological Society, London, Special Publications 340, 181-238.

Morsilli, M., Hairabian, A., Borgomano, J., Nardon, S., Adams, E. \& Gartner, G.B., 2017. The Apulia Carbonate Platform - Gargano Promontory, Italy (Upper Jurassic-Eocene). American Association of Petroleum Geology Bulletin 101, 523-531.

Mostardini, F. \& Merlini, S., 1986. Appennino centro-meridionale: sezioni geologiche e proposta di modello strutturale. Memorie della Societa Geologica Italiana 35, 177-202.

Ogg, J.G., Ogg, G.M. \& Gradstein, F.M., 2016. A Concise Geologic Time Scale 2016. Amsterdam (Elsevier), 234 pp.

Pomar, L., 2001. Types of carbonate platforms: A genetic approach. Basin Research 13, 313-334.

Pomar, L. \& Haq, B.U., 2014. Decoding depositional sequences in carbonate systems: Concepts vs experience. Global and Planetary Change 146, 190-225.

Read, J.F., 1982. Carbonate platforms of passive (extensional) continental margins: Types, characteristics and evolution. Tectonophysics 81, 195-212.

Read, J.F., 1985. Carbonate platform facies models. American Association of Petroleum Geologists Bulletin 69, 1-21.

Rolland, Y., 2017. Caucasus collisional history: Review of data from East Anatolia to West Iran. Gondwana Research 49, 130-136.

Rostovtsev, K.O., Agaev, V.B., Azarian, N.R., Babaev, R.G., Besnosov, N.V., Hassanov, N.A., Zesashvili, V.I., Lomize, M.G., Paitschadze, T.A., Panov, D.I., Prosorovskaya, E.L., Sakharov, A.S., Thodria, V.A., Topchishvili, M.V., Abdulkasumzade, M.R., Avanesian, A.S., Belenkova, V.S., Bendukidze, N.S., Vuks, V.Ya., Doludenko, M.P., Kiritchkova, A.I., Klikushin, V.G., Krimholz, G.Ya., Romanovskaya, G.M. \& Schevchen- ko, T.V., 1992. Yura Kavkaza [Jurassic of the Caucasus]. St. Petersburg (Nauka), 192 pp. (in Russian).

Ruban, D.A., 2006a. Taxonomic diversity dynamics of the Jurassic bivalves in the Caucasus: regional trends and recognition of global patterns. Palaeogeography, Palaeoclimatology, Palaeoecology 239, 63-74.

Ruban, D.A., 2006b. The Palaeogeographic Outlines of the Caucasus in the Jurassic: The Caucasian Sea and the Neotethys Ocean. Geološki anali Balkanskoga poluostrva $67,1-11$.

Ruban, D.A., 2008a. The Jurassic events in the Greater Caucasus basin (central Northern Neotethys) and the Neuquen basin (West Gondwana): A comparison. Revista de Asociación Geológica Argentina 63, 766-775.

Ruban, D.A., 2008b. Jurassic maximum flooding surfaces in the Greater Caucasus Basin (Northern Neo-Tethys). Central European Geology 51, 99-112.

Ruban, D.A., 2010a. Spatio-temporal patterns of the major Bathonian (Middle Jurassic) hiatus in the Greater Caucasus Basin (Northern Neo-Tethys Ocean) and its enigmatic origin. GeoActa 9, 21-30.

Ruban, D.A., 2010b. Diversity dynamics of Bajocian (Middle Jurassic) ammonites and transgressions/ regressions in the Caucasian Sea (northern Neo-Tethys Ocean): A case high-resolution test of probable dependence. Palaeogeography, Palaeoclimatology, Palaeoecology 297, 576-583.

Saintot, A., Brunet, M.-F., Yakovlev, F., Sébrier, M., Stephenson, R., Ershov, A., Chalot-Prat, F. \& McCann, T., 2006. The Mesozoic-Cenozoic tectonic evolution of the Greater Caucasus. Geological Society, London, Memoirs 32, 277-289.

Tendil, A.J.-B., Frau, C., Léonide, P., Fournier, F., Borgomano, J.R., Lanteaume, C., Masse, J.-P., Massonnat, G. \& Rolando, J.-P., 2018. Platform-to-basin anatomy of a Barremian-Aptian Tethyan carbonate system: New insights into the regional to global factors controlling the stratigraphic architecture of the Urgonian Provence platform (southeast France). Cretaceous Research 91, 382-411.

Williams, H.D., Burgess, P.M., Wright, V.P., Porta, G.D. \& Granjeon, D., 2011. Investigating carbonate platform types: Multiple controls and a continuum of geometries. Journal of Sedimentary Research 81, 18-37.

Manuscript received: 15 December 2018 Revision accepted: 27 April 2019 